MATIJA BRAČIĆ, Ph.D. ${ }^{1}$

(Corresponding author)

E-mail: mbracic@fpz.hr

STANISLAV PAVLIN, Ph.D. ${ }^{1}$

E-mail: spavlin@fpz.hr

RUŽICA ŠKURLA BABIĆ, Ph.D. ${ }^{1}$

E-mail: rskurla@fpz.hr

${ }^{1}$ University of Zagreb

Faculty of Transport and Traffic Sciences

Vukelićeva 4, 10000 Zagreb, Croatia
Traffic Management

Review

Submitted: 28 Feb. 2018

Accepted: 12 Dec. 2018

\title{
DELAY CAUSES DISTRIBUTION: EU VS CROATIAN COASTAL AIRPORTS
}

\begin{abstract}
The growth in air traffic in recent decades in Europe has consequently caused aircraft delays due to insufficient capacities of airspace and airports. Primary and reactionary delays at certain European and Croatian coastal airports in 2014 are analyzed in the paper according to CODA methodology and classified according to main flight delays causes. The largest share of delay minutes at the Croatian coastal airports (75\%) are related to reactionary delays, ranging from around $20 \%$ to $60 \%$ of total delay at the most congested European airports. Special emphasis is given to the analyses of rotational reactionary delay, and the results indicate that the share of reactionary delay in total delay at the Split airport is significantly higher compared to selected European airports, which may be explained by delays propagated from air traffic network and limited airport capacity. The total recorded delay at Croatian coastal airports is minor compared to total recorded delay in the European air traffic system, but delay patterns are quite similar, especially during peak summer months.
\end{abstract}

\section{KEY WORDS}

flight delay propagation; primary and reactionary delays; European airports;

\section{INTRODUCTION}

On-time performance of an airline schedule depends primarily on the capacity of the air traffic system, i.e., its subsystems (airports, air traffic control, and airlines), traffic demand, operating management system, and coordination between individual subjects. Delays are measured in minutes as the difference between scheduled and actual times of operation. Flight delays can be considered from the aspect of a system or an individual entity, i.e., aircraft operations in a specific subsystem.

According to definition, delay occurs when a planned activity is not realized at the planned time [1]. Delay represents a time interval between the scheduled time when a certain activity should have been realized and the actual time when the activity was realized. Also, delay can be considered as deviation from the appropriate time frame. Air traffic control for departure operations defines calculated take-off times (CTOT). A delay represents a deviation between the time frame ( -5 to +10 minutes) of the calculated takeoff time and the actual departure time.

In order to stimulate harmonized reporting between airlines, the International Air Transport Association (IATA) has defined a standardized system of codes that describe the kind and type of delay regarding its cause, which has been published in the Airport Handling Manual [2]. IATA has classified the delay codes into twelve basic groups with respect to delay causes.

According to IATA methodology, and from the aspect of airports and airlines, all delays that occur in an air traffic system can be divided into primary and reactionary delays. Primary delays can be defined as initial delays, i.e., those delays that are not affected by delays from previous flights. The causes of this type of delay can be diverse and depend on the current situation in an air traffic subsystem. Reactionary delays occur as a consequence of delays from previous flights and propagate further into the air traffic network. Such type of delay is also called "accumulated delays" [1].

A delay carried over from a previous flight can be a primary delay caused by some occurrence on that flight itself or a reactionary delay propagated from delays on earlier flights. Consequently, transfer passengers from delayed flights lose connection flights at the transfer airport. In that case, the carrier has to ensure the continuation of the passenger journey, resulting often in several hours of delays.

The European Organisation for the Safety of Air Navigation (EUROCONTROL) Central Office for Delay Analysis (CODA) defines two delay measures: average delay per flight and average delay per delayed flight [3]. Aircraft delays are caused partly also by inadequate airport management systems, i.e., insufficient airport capacities. Delays in air traffic systems can also affect the network model which is applied by certain airlines. 
Aircraft delays in air traffic systems have a negative effect on all involved parties, but if a delay is considered from the economic aspect, it has the most sig nificant influence on airlines. Aircraft delays directly affect aircraft fuel consumption, and research shows that fuel cost in 2016 accounted for about $20 \%$ of average airlines operating expenses [4]. Therefore, it is necessary to invest in airport infrastructure in order to meet traffic demand and reduce delays [5].

\section{LITERATURE OVERVIEW}

Jetzki, in the doctoral dissertation [6], deals with the topic of delay propagation in the European air traffic network. Among other things, the research showed that the calculated reactionary delays are significantly higher than reactionary delays reported by airlines. Studies have shown that in case of low-cost airlines reactionary delays account for $50 \%$ of all delays at the annual level. Hub and spoke operations have the smallest share of reactionary delays in total delays, $40 \%$, whereas point-to-point flights have a level of reactionary delays of $45 \%$ in relation to total delays.

Reynolds-Feighan and Button [7] focused on the issue of airport delays and identified trends in the delay pattern and the most penalized European airports during the last two decades of the twentieth century. They concluded that traffic level has the greatest interrelation with overall delay (i.e., departure and arrival), and that simple correlation between total delay and average passenger/movement is 0.37 .

In the framework of the SESAR WP-E TREE project, Campanelli et al. [8] developed a model for characterizing and forecasting the spreading of reactionary delays in the ECAC area.

The model comprehends aircraft rotation, passenger connectivity, and airport congestion as well as crew rotation, and is specifically focused on the European network, including mechanisms for Air Traffic Flow Management (ATFM) slot reallocation and swapping.

Liu et al. [9] proposed an optimized Ground Delay Program (GDP) strategy under uncertain airport capacity. The proposed GDP strategy has the potential to effectively reduce the overall delay while maintaining the ATC safety risk on an acceptable level.

Baspinar et al. [10] investigated the effect of local disturbances (weather effects, air traffic controller strikes, etc.) at European airports over the global delay characteristics of an air traffic network. The model for simulating delay propagation across the network was used for generating various scenarios where the airport capacities were reduced under local disturbances, and the consequences of these local capacity reductions on total network delay (departure + arrival) were analyzed.
Bai, in the doctoral dissertation [11], developed a statistical model of airport delay and single flight arrival delay. The model is based on the statistical tools: multivariate regression, ANOVA, neural networks, and logistic regression. Implementation of the model was tested at the Orlando International Airport.

$\mathrm{Xu}$, Donohue, Laskey, and Chen [12] proposed the use of Bayesian networks to investigate and visualize delay propagation among airports. Their research demonstrated the utility of Bayesian networks as a tool for studying how subsystem-level causes propagate to system-level effects.

Apart from that, $\mathrm{Xu}$ et al. in [13] described a stochastic Bayesian network model to analyze the relationships between delay variables and the factors that cause delays. The methodology was demonstrated on a case study analysis of two routes: Chicago O'Hare Airport to Atlanta Airport (ORD-ATL) and LaGuardia Airport to Atlanta Airport (LGA-ATL). It has been found that departure delays at the hub airports ORD and LGA were the primary reason for the over one-hour delay at the destination airports. When the cascading delay exceeded 30 minutes, more than $80 \%$ of flights reduced their actual turnaround time at the discussed airports.

An extensive overview of more than 50 potential factors that influence flight delay is given by $\mathrm{Xu}$ et al. [14]. Authors have created models to predict aggregate delays at airports by using "Multivariate Adaptive Regression Splines". The models, based on 34 OEP (Operational Evolution Partnership) airports, indicated that the mean transformed absolute prediction error for generated delay models is 5.3 minutes while this value for absorbed delay models is 2.2 minutes.

Whereas Campanelli et al. [15] performed a comparison of the European and American air traffic system from the aspect of delay propagation, the results have shown that the first-come-first-served system causes significantly greater saturations than the ATFM slots priority system. The problem of airborne delays and the possibility of their recovery have been dealt with in the paper [16]. The methodology of airborne delays detection is based on comparison between the actual and planned trajectories of aircraft flight.

Silva, Verhoef, and van den Berg [17] studied the correlation between the number of routes and delays in the conditions of different network models, and the results show a higher percentage of delayed flights in hub airports in comparison with other airports.

The influence of saturation in hub and spoke system on the operations and departure delays on the US airline market was studied in papers $[18,19]$.

In the paper [20], Wang et al. developed a simple analytical model, which separates the controllable factors that influence delays and delay propagation in the National Airspace System from those factors that are random variables. 
Cook, Tanner, Williams, and Meise [21] developed a decision-support tool for managing flight delay costs in the pre-departure and airborne phases of a flight. The dynamic cost indexing tool trades accelerated fuel burn against 'cost of time' and environmental impact.

Forbes [22] considered the influence of air traffic delay on the airline prices, and the research addressed US airports. The results show that the prices decrease with every minute of delay by 1.42 USD for direct passengers, i.e., 0.77 USD for transfer passengers due to passenger compensation.

In research done at the University of Westminster [23], the influence of delay on airline operating costs was processed statistically. Among other delays, it was found that ATFM delays in the entire European air traffic network caused to airlines a total cost of 1.25 billion USD, i.e., every minute of ATFM delay caused an expense of 81 euros.

Airport delays have different causes, and they affect aircraft operation directly. The problem is especially notable at large airports, as well as at regional airports with seasonal character, inadequate operating management system, and limited capacities of single subsystems. The study [24] assesses the impact of delays and cancellations by considering their effect on the entire travel itinerary. The research considers the influence of regional flights (flight between a regional airport and hub airport) on the entire trip. The research shows that passengers on $16.4 \%$ connecting itineraries would face a missed connection due to delay or cancellation. Also, an average delay time of 68 minutes on the initial flight would lead to an average arrival delay of 90 minutes across all itineraries, while a cancellation would lead to an arrival delay of over 10 hours.

\section{AIRPORT CLASSIFICATION METHODOLOGY}

The airport system can be observed as an interaction point of three main air traffic subsystems: airport (with all its subsystems), air traffic control, and airlines. Operation planning must be performed in collaboration with all involved parties, in order to achieve a balance between the capacities of the current resources and the traffic demand [25]. Inadequate collaboration results in negative consequences: imbalance between demand and airport capacity, lower level of service, substantial level of delay, increased costs for all users, lower level of security, etc.

Airports can be classified according to different elements:

- Traffic levels;

- Type of traffic (hub airports, international airports, national airports, regional airports);

- Air traffic modes (conventional/traditional airlines, low-cost airlines, cargo airlines, charter airlines);

- Traffic characteristics (seasonal, non-seasonal);

- Air traffic control service levels, etc.

At the end of the 1970s, Great Britain developed an airport classification system as guidelines for capital investments in airport systems [26].

According to this classification, airports were divided into four categories: gateway international airports that cover a wide range of international and national connections including intercontinental connections; regional airports that meet the traffic demand of a certain region including short international (mainly towards the Scandinavian countries) and national connections; local airports that serve scheduled passenger traffic with smaller types of aircraft (up to 25 seats) and charter flights; aerodromes for general aviation.

The European Committee of the Regions in its Community guidelines on financing of airports and start-up aid to airlines departing from regional airports defined four categories of airports presented in Table 1 [27].

According to the European Committee of the Regions, regional airports belong primarily to categories $\mathrm{C}$ and $\mathrm{D}$ but under certain conditions also to category $B$ [27].

\section{REGIONAL AIRPORTS' TRAFFIC SHARE}

The influence of regional airports with traffic up to 5 million passengers yearly (airports $C$ and $D$ categories) on the European air traffic system can be considered through their share in the total traffic. In this context, regional airports account for $21 \%$ of the total traffic thus representing a significant factor that influences the entire system.

Table 1 - Airports classification according to the European Committee of the Regions

\begin{tabular}{||c|c|c|c|c||}
\hline $\begin{array}{c}\text { Airport } \\
\text { category }\end{array}$ & Airport type & Annual passenger volume & $\begin{array}{c}\text { Number of } \\
\text { airports }\end{array}$ & $\begin{array}{c}\text { Approximate share of } \\
\text { European air traffic [\%] }\end{array}$ \\
\hline \hline A & Large Community airports & more than 10 million & 20 & 65 \\
\hline B & National airports & $\begin{array}{c}\text { between 5 and 10 } \\
\text { million }\end{array}$ & 15 & 14 \\
\hline C & Large regional airports & $\begin{array}{c}\text { between 1 and 5 } \\
\text { million }\end{array}$ & 57 & 17 \\
\hline D & Small regional airports & less than 1 million & 67 & 4 \\
\hline
\end{tabular}

Source: [27] 
In 2013, EUROCONTROL published a list of airports that significantly affect the European air traffic network [28]. The primary objective of this document is to define airports whose specific characteristics can have significant influence on the performance of the European air traffic network. The list contains a total of 191 airports within the European air traffic system, and it has been defined on four basic criteria. Every criterion contains a certain weight factor, and the sum of all factors determines the position of a certain airport on the list. The first criterion is whether the airport belongs to the coordinated airports according to the classification defined by the IATA. The maximal weight factor according to this criterion is 0.75 .

The second criterion represents the total number of Instrument Flight Rules (IFR) operations, and based on this criterion it is possible to achieve a maximal weight factor of 1.35. The share of delays in the total number of IFR operations represents the third criterion with a maximal weight factor of 5.65. The last criterion is the influence of seasonality, i.e., distribution of traffic during the year (summer/winter peak period), and the maximal weight factor for this criterion is 2.25.

According to this document, regional airports participate with more than $25 \%$ in the total number of airports in the European air traffic system. The mentioned airports are characterized by limited infrastructural capacity and significant peak periods during the year.

\section{AIR TRAFFIC NETWORK PERFORMANCE MEASURES}

The International Civil Aviation Organization has identified key performance indicators (KPI) and defined 11 key performance areas [29].

The document EUR Region Performance Framework, based on the ICAO provisions and the initiatives on regional and national levels, has defined a list of significant, realistic, and measurable indicators applicable in the entire EUR region, which covers 52 countries [30].

This document identifies six key performance areas: safety, capacity, efficiency, environment, cost efficiency, and participation of air traffic management (ATM) community.

Airport benchmarking represents a group of measurable indicators that define the operative efficiency of an airport [31]. Benchmarking can be considered regarding two types of comparisons: internal and external. In internal benchmarking only key performance indicators of a certain airport are compared with themselves, i.e., the KPI comparison is performed for a certain time period [31]. In external benchmarking, the KPIs of an airport are compared with the KPIs of other airports or KPIs obtained by "best practice". Airport Council International (ACl) classifies all KPI indicators in one of six key performance areas: core, safety and security, service quality, productivity/efficiency, financial/commercial, and environmental [31].

Airport system performance is measurable through the parameter of aircraft delay within the airport system. It is necessary to distinguish reactionary delays from delays generated by the airport system. If the delay of an aircraft on departure is greater than the delay that the same aircraft has when it arrives at the airport system, then the delay generated by the airport system is the difference between the arrival and departure delays.

Aircraft delay in an air traffic system has a stochastic character; in most cases it cannot be predicted, and neither can its duration and influence on aircraft operations. Aircraft delay may occur in all phases of an aircraft flight, as well as during movement and the ramp handling process at the airport. The main indicator showing that a delay has occurred is a mismatch between the actual time and scheduled time of an aircraft operation.

At the global level, IATA delay codes are used for the analysis and measuring of aircraft delay in air traffic systems. At the European level, EUROCONTROL delay codes are also used, primarily to group ATFM delays according to their cause [32]. In addition, certain airlines use their own codes for recording the type and duration of aircraft delay, which enable them to describe specific characteristics that occur in a particular process more adequately and to consequently analyze the delays. Airlines' codes are much more complex than IATA delay codes, and they often contain many sub-codes that are related to specific activities of a single airline. The number of airlines that use their own codes to record delays is extremely low, so those are not taken into further consideration.

The Performance Scheme for Air Navigation Services and Network Functions is a fundamental element of the Single European Sky legislative package (SES II) that was adopted by the European Union in 2009 to contribute to sustainable development of the air transport system by improving the overall efficiency of air navigation services across the key performance areas of safety, environment, capacity, and cost-efficiency.

As the first step in the implementation of the Performance Scheme Regulation (Commission Regulation (EU) No 691/2010), the European Commission adopted EU-wide performance targets and alert thresholds for the provision of air navigation services for the first reference period (RP1: 2012-14). The capacity target for RP1 (an improvement of the average en-route ATFM delay in order to reach a maximum of 0.5 minutes per flight in 2014) was designed to avoid major disruptions and indirect costs for airspace users and their passengers. 
The majority of performance schemes nearly meet the reference values provided by EUROCONTROL for en-route ATC capacity, including in the densest part of Europe. However, the current performance schemes collectively reached $0.76 \mathrm{~min} /$ flight in 2014.

This falls short of the EU-wide capacity target $(0.5$ $\mathrm{min} /$ flight) by a relatively small margin in delay terms, but leads to financially significant consequences for airspace users. Some $€ 920 \mathrm{M}$ of additional delay costs could have been saved over RP1 if the EU target had been met [33].

Commission Implementing Regulation (EU) No 390/2013 laying down a performance scheme for air navigation services and network functions entered into force in May 2013 and applies to the second reference period (RP2: 2015-19) [34]. Performance during RP2 has led to the EU-wide targets not being met. Delays increased significantly during the second half of RP2 because capacity did not meet the increased demand in a number of key locations in Europe. En-route ATFM delay per flight reached 0.94 minutes in 2017, 0.44 minutes per flight above the target value [35].

\section{EUROPEAN AIRPORTS PERFORMANCE}

In 2002, the Central Office for Delay Analysis (CODA) was founded as part of EUROCONTROL. Its purpose is to analyze and process the data on delays that occurred in the European Civil Aviation Conference (ECAC) member states. The objective of the EUROCONTROL Central Office for Delay Analysis is to provide verified and comprehensive information about the current state regarding delays to all relevant involved parties in the European air traffic system.

The Central Office for Delay Analysis defines two delay measures: average delay per flight and average delay per delayed flight [3]. Average delay per flight (ADM) is equal to the sum of all delay minutes on departure divided by the total operated flights. Flights leaving ahead of schedule are delay neutral.

CODA also defines the average delay per flight on departure (ADMD) and the average delay per flight on arrival (ADMA) (Equations 1 and 2).

$$
A D M D=\frac{\sum_{\text {If ATD }>S T D}(\text { ATD }-S T D)}{\text { Number of Departures }}
$$

where:

$A T D$-actual time of departure (from the gate),

$S T D$-scheduled time of departure (from the gate).
ADMA $=\frac{\sum_{\text {If ATA }>\text { STA }}(\text { ATA }- \text { STA })}{\text { Number of Arrivals }}$

where:

$A T A$ - actual time of arrival (at the gate),

$S T A$ - scheduled time of arrival (at the gate).

Average delay per delayed flight (ADD) is the sum of all delay minutes (for all causes) in departure divided by the number of delayed flights.

The statistics is based on a voluntary system of reporting, primarily by the airlines, but also by the airports and service providers in air navigation. There are more than 200 partners from more than 44 countries participating in the reporting system, and the system itself comprises IFR flights [32]. In 2014, the CODA system covered approximately $69 \%$ of all IFR flights in the ECAC states on average.

Analyses show that the average delay per delayed flight (ADD) for all causes in 2014 amounted to 26.0 minutes, which represents a decrease of 0.7 minutes compared to the previous year.

The Central Office for Delay Analysis data indicate that in the European air traffic system, the average delay (in 2014) amounts to 9.7 minutes per flight (for all causes).

In the period 2014-2016, within the ECAC region, ADM increased on average by $6.3 \%$ while the number of flights increased on average by $2 \%$ (Table 2). The reason for the disproportionate increase between ADM and number of flights is insufficient airport and airspace capacities which did not adequately meet the traffic demand.

CODA processes arrival and departure delays separately and classifies them into seven groups depending on the time interval.

Reactionary delay has the largest share in the total aircraft delay per single flight for 2014 and amounts to 4.32 minutes. Other delays were caused by the airlines (3.04 minutes), capacity of the airport airspace (0.66 minutes), en-route capacity (0.44 minutes), etc. (Figure 1).

Generally, total delay in air traffic can be considered from the aspect of four main factors that generate delay: (1) airlines, (2) air traffic controls, (3) airports, and (4) meteorological conditions.

Figure 2 shows the distribution of the four main factors that affected the delay in the air traffic system in 2013 and 2014 according to the data collected by airlines.

Table 2 - Comparisons of average delay per flight and number of flights increase within the ECAC region in the period 2014-2016

\begin{tabular}{|c|c|c||}
\hline Year & $\begin{array}{c}\text { Average delay per flight } \\
\text { increase rate compared to previous year }\end{array}$ & $\begin{array}{c}\text { Number of flights } \\
\text { increase rate compared to previous year }\end{array}$ \\
\hline \hline 2014 & $3.2 \%$ & $1.7 \%$ \\
\hline 2015 & $7.2 \%$ & $1.5 \%$ \\
\hline 2016 & $8.6 \%$ & $2.8 \%$ \\
\hline
\end{tabular}

Source: [32, 36, 37] 


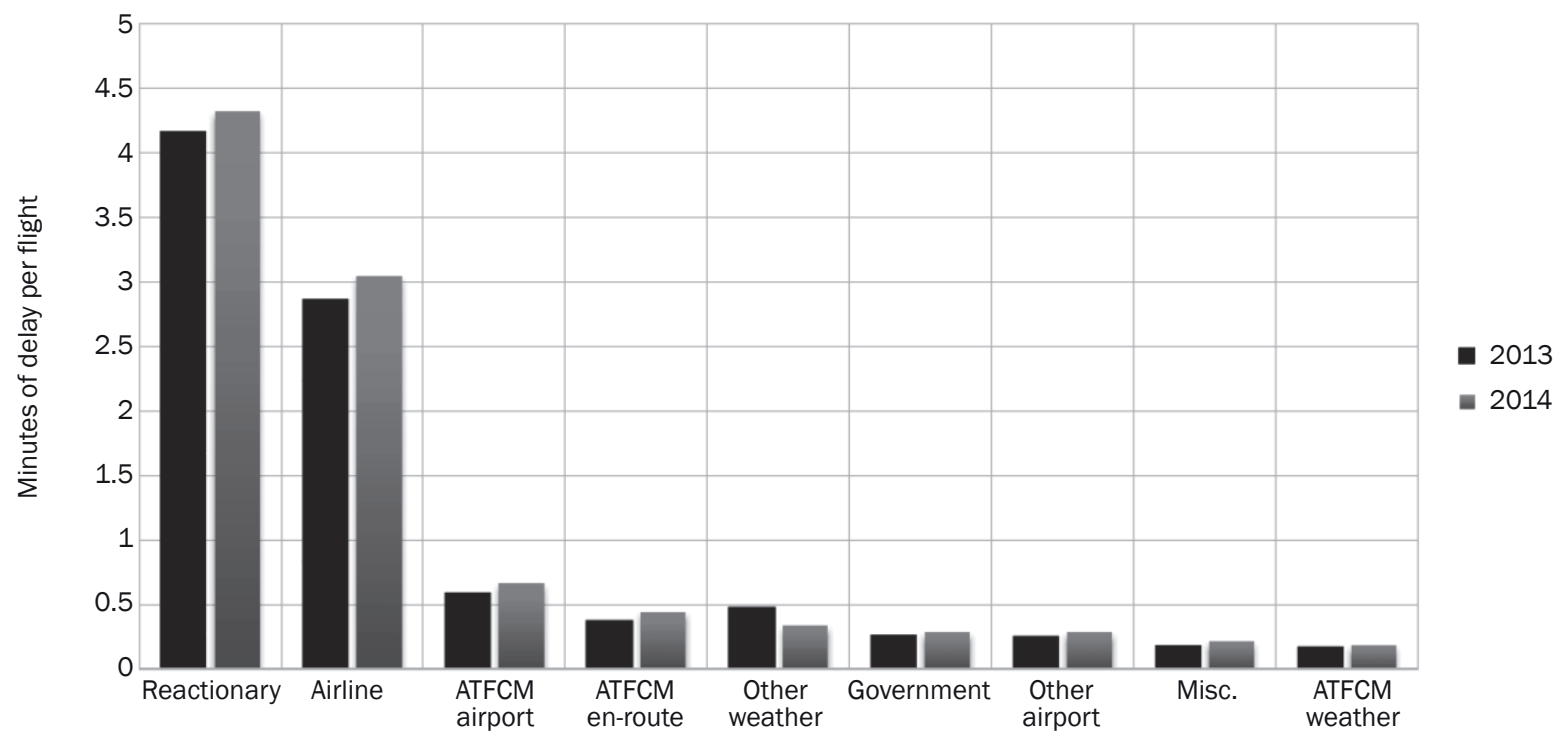

Figure 1 - Distribution of primary and reactionary flight delays in the ECAC member states for 2013 and 2014 Source: [32]

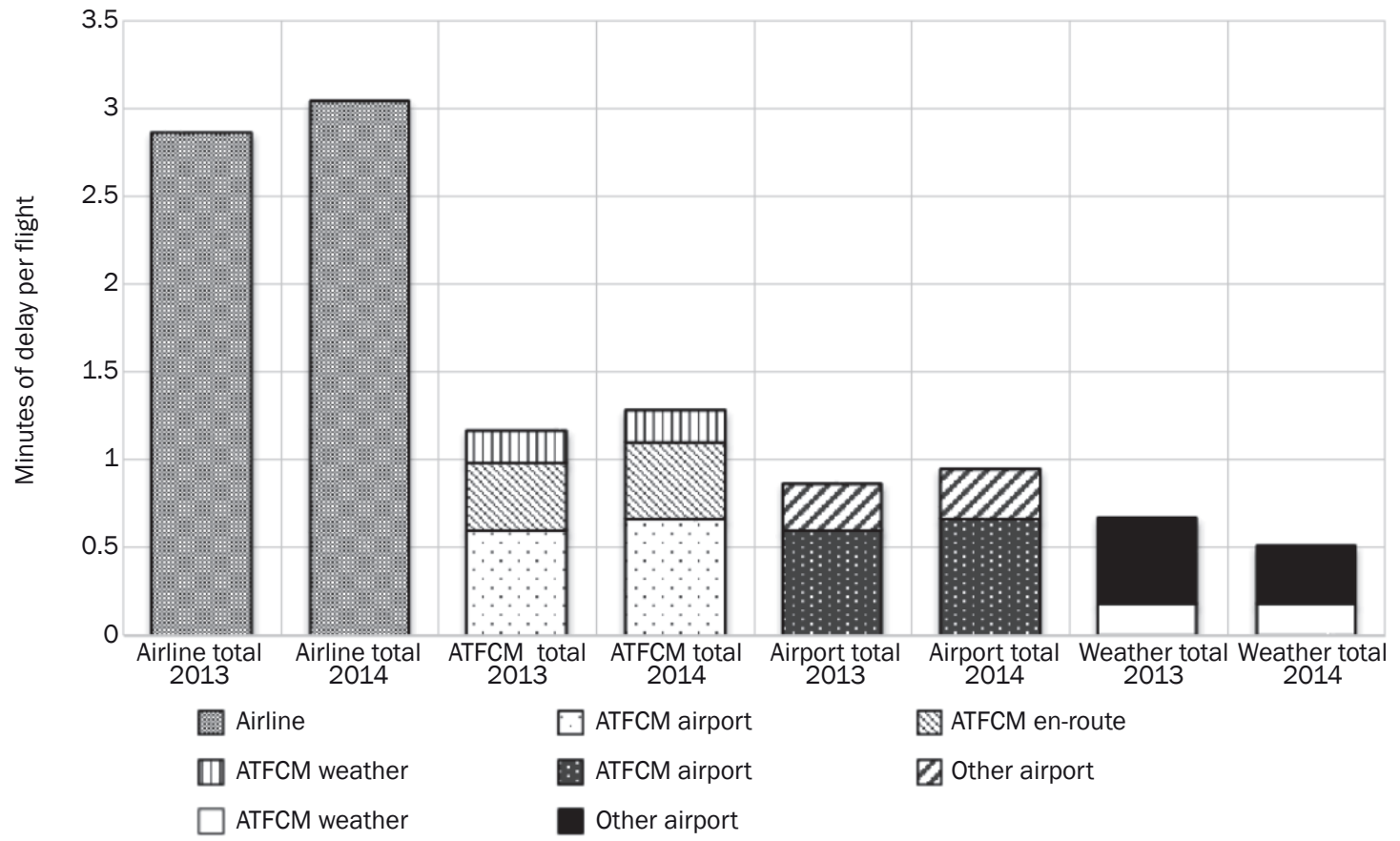

Figure 2 - Distribution of four main factors that affected flight delay in ECAC member states for 2013 and 2014 Source: [32]

The analysis of Figure 2 shows that the largest share in the total delay per single flight in 2014 was generated by the airlines with 3.04 minutes. Other delays were caused by the air traffic control with 1.27 minutes, airports with 0.93 minutes, and meteorological conditions with 0.51 minutes. The comparison of trends in 2013 and 2014 shows an increase in the segments of delay caused by airline, air traffic control, airports, and a decrease in the segment of meteorological conditions.

\section{CROATIAN REGIONAL AIRPORTS PERFORMANCE}

Republic of Croatia has five coastal international airports and two aerodromes. In 2014, the Croatian regional costal airports recorded 58,453 aircraft operations and 4,266,455 passengers [38]. The Split and Dubrovnik airports accounted for $77 \%$ of the total traffic at the Croatian coastal airports. 


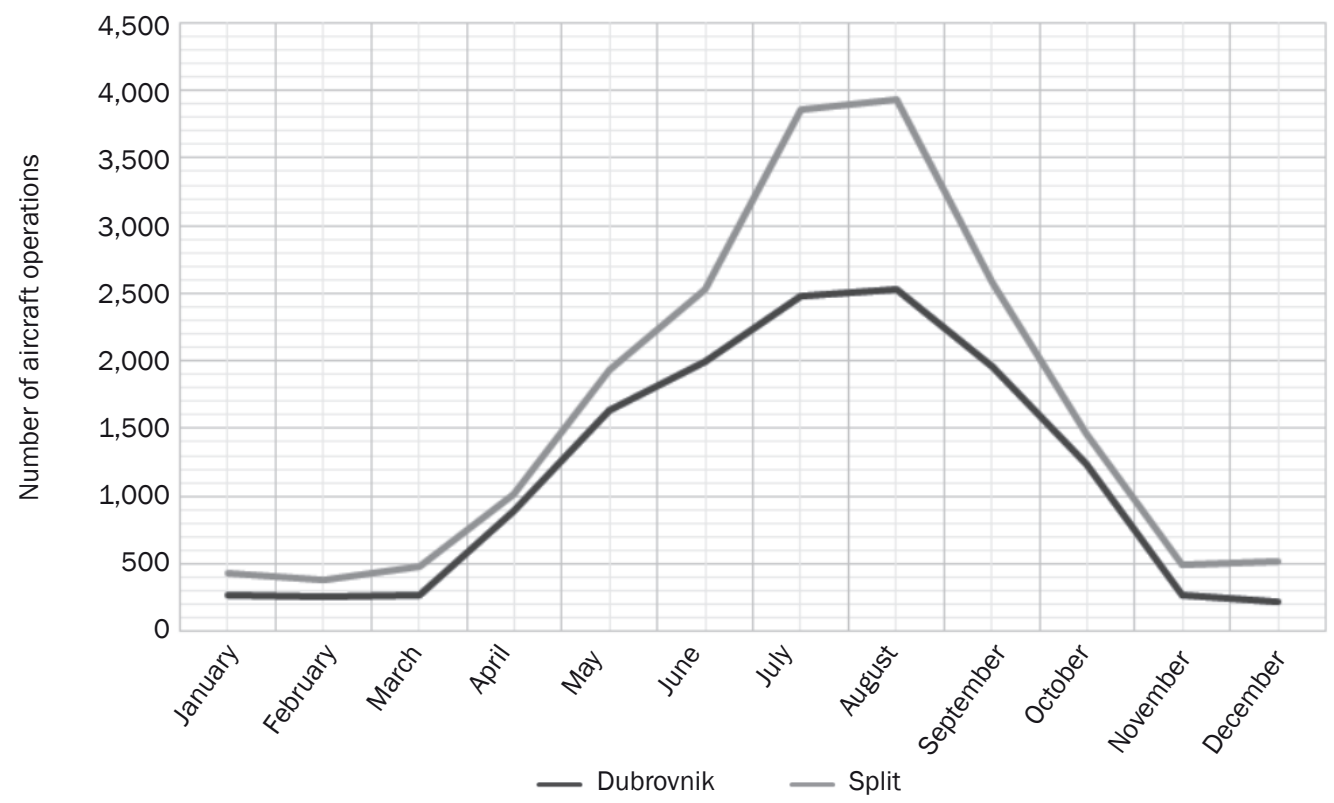

Figure 3 - Distribution of aircraft operations at Dubrovnik and Split airports in 2014 Source: [38]

The primary role of the Croatian coastal airports is to enable the arrival of international tourists from the emitting tourist regions. The coastal airports have a seasonal character, i.e., traffic at coastal airports is unevenly distributed during the year. During the summer months, the number of aircraft operations, depending on the airport, is approximately ten times higher than during the winter months (Figure 3).

According to the guidelines of the European Committee for Financing Airports and support for starting of airlines who operate from regional airports, these airports are classified to category $C$ (big regional airports) while the rest are in the category $D$ (small regional airports).

Due to their seasonal character and influence on the European air traffic system, the Split and Dubrovnik airports (airports belong to category C) have been analyzed in this paper.

\subsection{Benchmarking of Croatian regional coastal airports}

Since there is no central office that processes the delays that occur in the Croatian air traffic system, airports record and process delay statistics using CODA methodology on their own.

The average delay at Split Airport is $\mathbf{5 . 2 1}$ minutes per flight (for all causes), and at Dubrovnik Airport it is 4.67 minutes per flight (for all causes) [39, 40].

The analysis of the top three airports in Croatia (according to the number of handled passengers) from the aspect of delay indicates that the Croatian airports follow the trends of the European airports.
If only delayed flights are considered, the average delay per delayed flight at Split Airport is 21.3 minutes, whereas at Dubrovnik Airport it is 24.6 minutes [39, 40]. The distribution of delays according to the number of events and the duration of delay for Split Airport and Dubrovnik Airport are presented in Graphs 7.2 and 7.3. The analysis of delay is based on IATA delay codes (10 to 99) and internal delay codes of airlines (0 to 9). Figures 4 and 5 show the number of occurrences for all IATA delay codes except code 93 (reactionary delay).

In 2014, Split Airport recorded a total of 4,796 aircraft operations with delay, whereas Dubrovnik Airport recorded a total of 2,656 .

The most significant delay recorded at the observed airports is reactionary delay (IATA delay codes 91-96). The group of delays designated by IATA delay codes 81-84 refers to ATFM restrictions and makes the second most frequent delay at the airports. The problems related to these types of delays result from the geo-location of these airports. Both airports are located in the vicinity of mountains (on the northern and north-eastern side, respectively), which means their airspace is unavailable for arrival and departure operations. The delays related primarily to aircraft handling, marked in the graph by IATA delay codes from 31 to 39 , are a consequence of extreme traffic seasonality at the observed airports.

IATA delay codes 61 to 69 have a significant share in the total delay, but this group is primarily related to airlines and is not analyzed in this paper.

The codes that indicate delays in cargo operations have not been recorded since there are no cargo flights from the mentioned airports (Figure 5 shows IATA delay codes from 21 to 29 ). 


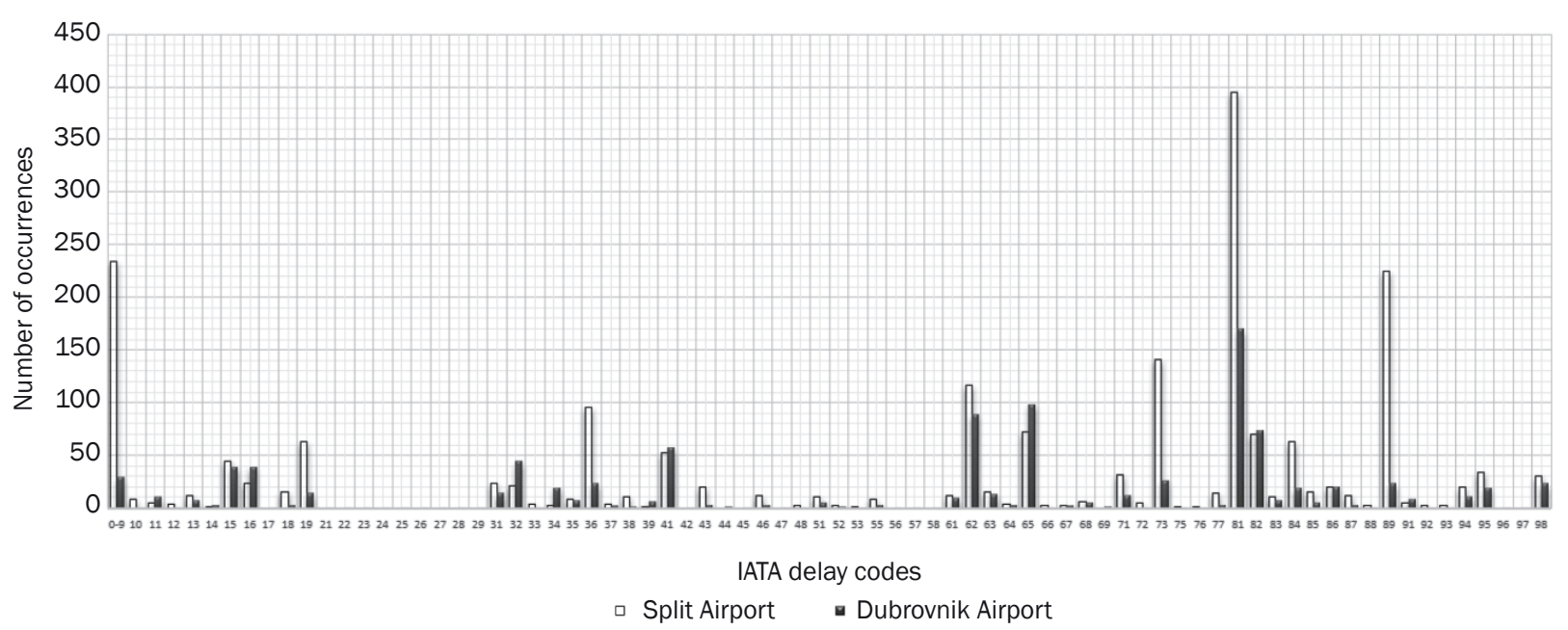

Figure 4 - Distribution of delays according to IATA codes for 2014 at Split and Dubrovnik airports

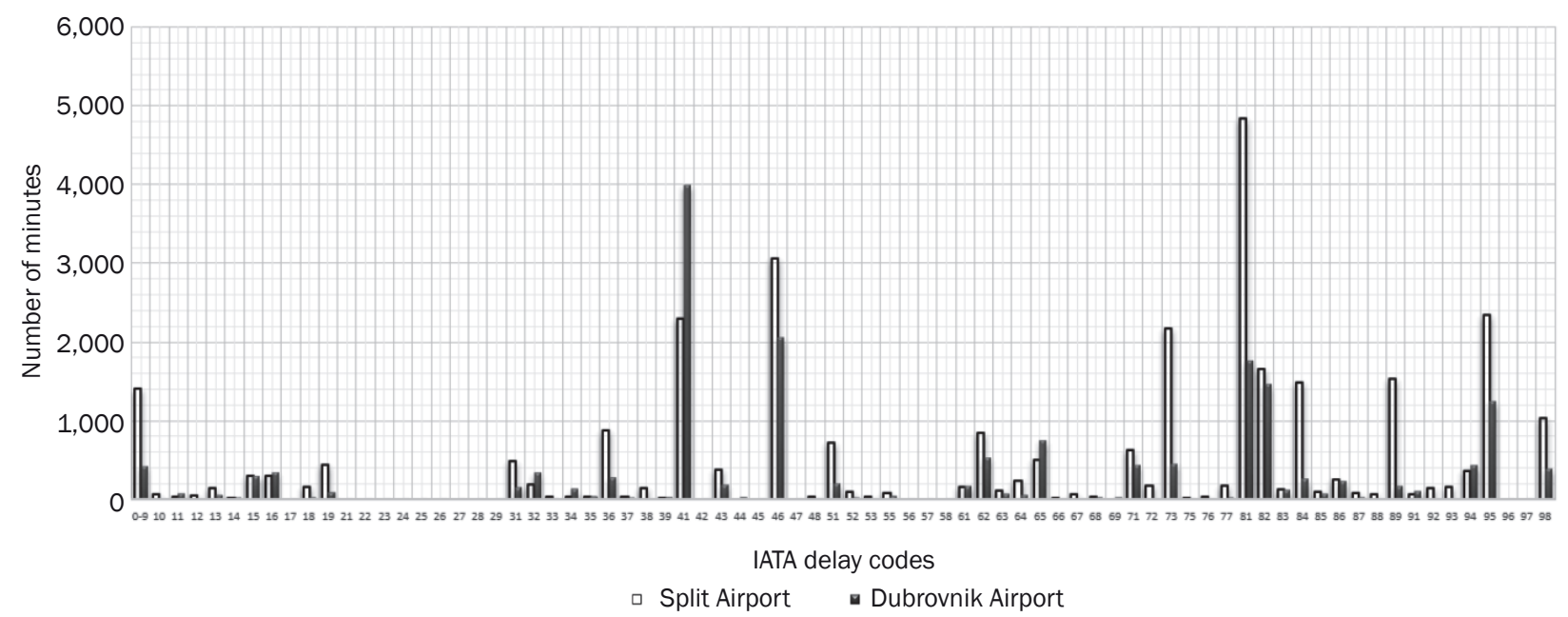

Figure 5 - Distribution of delays according to IATA codes at Split and Dubrovnik airports

The analysis of the aircraft operations at Split Airport indicates that in 2014 a total of 102,347 minutes of delay were recorded, whereas this value at Dubrovnik Airport was 65,530 minutes. Although both airports recorded similar traffic values, the reason of the higher number of delay minutes at Split Airport is the limited capacity of the maneuvering area that generates additional delays.

The highest number of delays is generated by Croatia Airlines, which has the highest number of recorded operations at the observed airports.

A detailed analysis of aircraft operations indicates that the departure delays of aircraft are significantly affected by arriving delays that further propagate into the air traffic network (IATA delay code 93).

Figures 4 and 5 show the correlation between the number of recorded delays and recorded delay minutes. The exceptions are the technical delays and delays related to aircraft equipment which result with a relatively low number of delays, but a large number of delay minutes.
The distribution of delays during the year should be considered for comprehensive analysis of airport delays especially at regional airports with unevenly distributed traffic during the year.

The data from Split Airport have been processed and the results are presented in Figure 6 . The analysis of delay duration is based on IATA delay codes (10 to 99) and internal delay codes of airlines (0 to 9).

The analysis of aircraft delays at Split Airport in 2014 indicates that the delay distribution corresponds with aircraft operations distribution, i.e., during two peak months (July and August) significant delays in the airport system were recorded. The ratio of aircraft delays in the peak month and the month with lowest traffic equals 40 , while the ratio of aircraft operations for the same months equals 10 . Aircraft delay on departure grows exponentially with the increase of traffic as a consequence of insufficient capacities and operating management system. 


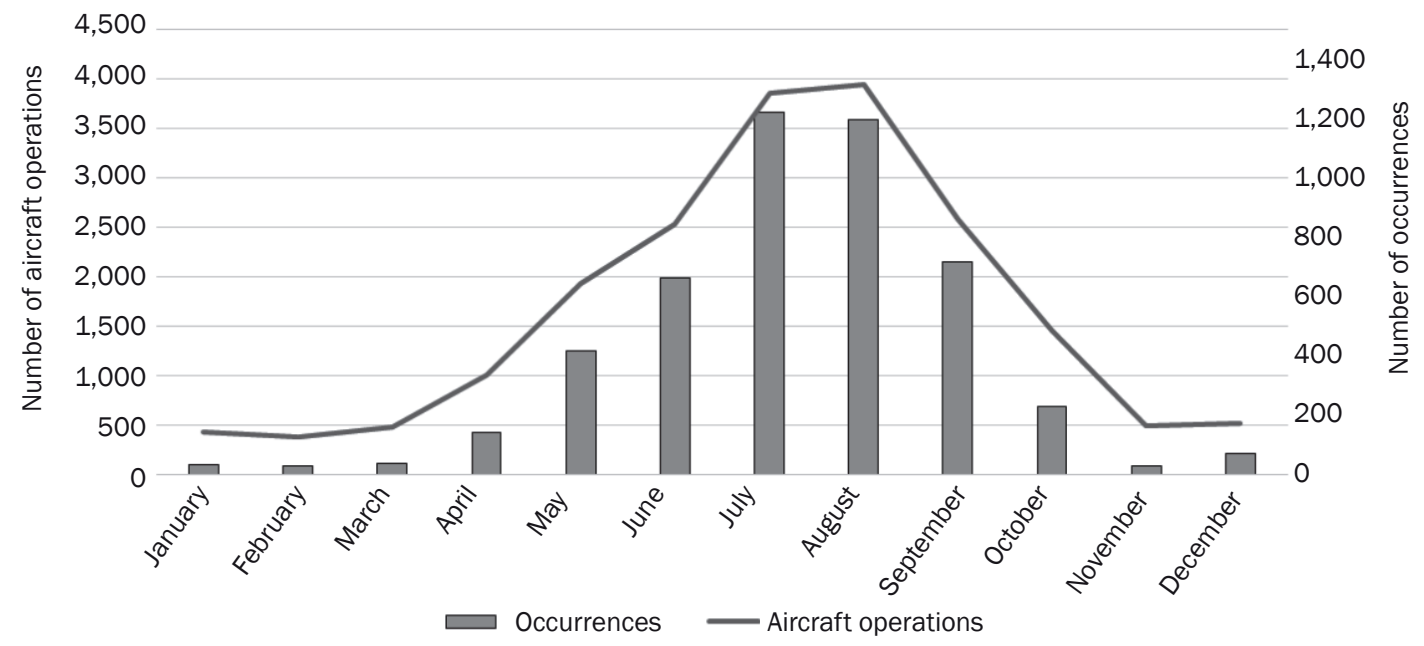

Figure 6 - Distribution of delays and aircraft operations at Split Airport in 2014

\subsection{Croatian regional coastal airports within the European air traffic system}

The delay analysis indicates that the Split and Dubrovnik airports follow the trends of the European air traffic system. If the level of delays recorded at these airports is considered, it may be concluded that the total recorded delay is minor in relation to the total recorded delays in the European air traffic system. A comparative delay analysis of the Croatian regional coastal airports and the European air traffic system shows that there is a certain correlation between them.

A comparative analysis of the recorded data indicates that in the European air traffic system the average delay (in 2014) amounted to 9.7 minutes per flight (for all causes), whereas at Split Airport it amounted to 5.21 minutes per flight (for all causes), and at Dubrovnik Airport to 4.67 minutes per flight (for all causes). If only the peak summer month (July) is considered, the average delay at Split Airport amounted to 7.13 minutes per flight (for all causes). If the average delay per delayed flight is observed, there is also a direct correlation between the Croatian regional coastal airports and the European air traffic system.

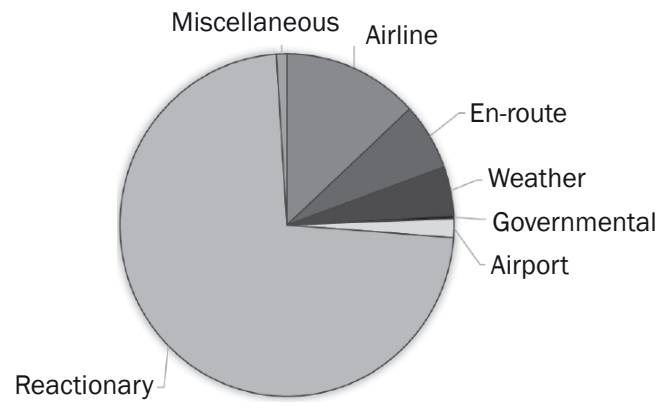

a) Split Airport
According to the CODA methodology, all delays can be classified into one of the seven delay groups, while the first six groups refer to primary delays, whereas the seventh delay group refers to reactionary delays (Table 3).

Using the CODA methodology, delays from Split and Dubrovnik Airport were processed, and the results are shown in Figure 7.

An analysis of Figure 7 indicates that the delays at those airports have a similar behavioral pattern. The majority of delay minutes, i.e., $75 \%$ of them, are

Table 3 - Delay classification according to CODA methodology

\begin{tabular}{|l|c||}
\hline \multicolumn{1}{|c|}{ CODA delay group } & IATA delay codes \\
\hline \hline Airline & $11-69$ and ${ }^{*}$ \\
\hline Airport & $87-89$ and 83 \\
\hline En-route & $81-82$ \\
\hline Governmental & $85-86$ \\
\hline Weather & $71-79$ and 84 \\
\hline Miscellaneous & $98-99$ \\
\hline Reactionary & $91-96$ \\
\hline
\end{tabular}

* Other airline related causes Source: [32]

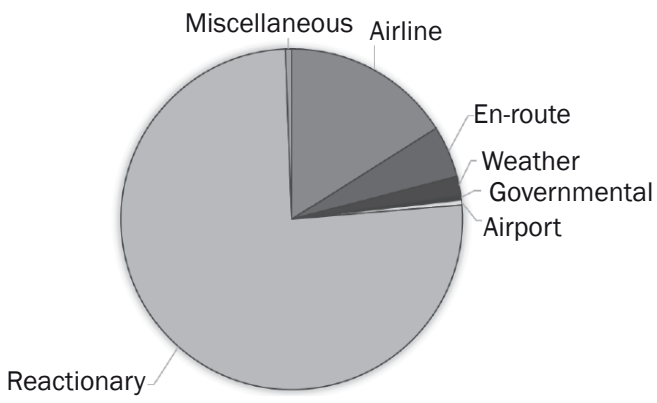

b) Dubrovnik Airport

Figure 7 - Main delay causes grouped by CODA methodology 
related to reactionary delays, followed by delays related to the airlines which account for about 15\% of the total reported delay minutes. If the data from Figure 7 is compared with data from the ten most congested European airports, certain deviations are evident. The largest share of delays at the most congested European airports are reactionary delays, which range from around $20 \%$ to around $60 \%$ of total delays, while the second most frequent delays are related to the airlines, ranging from around $20 \%$ to around $40 \%$.

The share of reactionary delays (IATA code 93) in relation to the total number of delays for 2014 at the European air traffic network and at Split Airport per months is presented in Table 4.

The analyses of the European air traffic system indicate that the share of reactionary delay (IATA code 93) in the total delay amounts to approximately $40 \%$. The distribution of reactionary delays (IATA code 93) per months in 2014 indicates that a slightly lower level of reactionary delays is present during the winter months (from November to March). In that period, reactionary delays could be compensated through airport operations due to lower traffic volumes.

The analysis of the aircraft operations at the Split Airport indicates that the share of reactionary delay (IATA code 93 ) is between $48 \%$ and $82 \%$, which is a significantly higher level compared to other European airports. That level is a consequence of delay propagation from air traffic network and limited airport capacity.

From the aspect of airports, aircraft delay on arrival represents one of the significant factors that cause a disturbance in the flight schedule at the airport and delays aircraft operations. Aircraft delays on arrival have a stochastic character and cannot be predicted in advance nor can their influence on aircraft operations at airports be estimated.

Table 4 - Share of code 93 for selected European airports and Split Airport in 2014

\begin{tabular}{||l|c|c|}
\hline \multicolumn{1}{|c|}{ Month } & Europe & Split Airport \\
\hline \hline January & $38 \%$ & $48 \%$ \\
\hline February & $38 \%$ & $57 \%$ \\
\hline March & $36 \%$ & $64 \%$ \\
\hline April & $40 \%$ & $79 \%$ \\
\hline May & $42 \%$ & $71 \%$ \\
\hline June & $42 \%$ & $74 \%$ \\
\hline July & $43 \%$ & $69 \%$ \\
\hline August & $41 \%$ & $71 \%$ \\
\hline September & $42 \%$ & $64 \%$ \\
\hline October & $40 \%$ & $77 \%$ \\
\hline November & $35 \%$ & $82 \%$ \\
\hline December & $39 \%$ & $54 \%$ \\
\hline \hline
\end{tabular}

\section{CONCLUSION}

The present issue of air traffic in Europe are delays, i.e., system capacities that together with current operating management systems do not adequately match traffic demand. Operational implications are reflected in flight delays with negative consequences both for airlines and airports.

As part of the European air traffic system there are 124 regional airports (C and D category airports) representing $21 \%$ of European airport traffic. Considering the airports that significantly affect the European air traffic network, $25 \%$ of them are categorized as regional airports, which shows their significances.

In 2014, the average delay per flight amounted to 9.7 minutes (for all causes), whereas the average delay per delayed flight was 26.0 minutes (for all causes) in the European air traffic system. The current state of the European air traffic system indicates that the most significant cause that influences aircraft on-time performance is reactionary delay.

This aircraft delay results from a delayed arrival of the aircraft (and/or crew) from a previous flight, and it propagates further into the air traffic network. The delays on arrival that occur also because of insufficient airspace capacity cause additional annual expenses to airlines, which in Europe exceed a billion euros.

The delay statistics from Croatian airports indicate a similar trend as at other European airports. The average delay at Split Airport amounts to 5.21 minutes per flight (for all causes), and at Dubrovnik Airport 4.67 minutes per flight (for all causes), whereas the average delay per delayed flight at Split Airport amounts to 21.3 minutes, and at Dubrovnik Airport 24.6 minutes. The research results indicate that the average delay per delayed flight at Split Airport is about 20\% lower, whereas at Dubrovnik Airport it is about $8 \%$ lower than to the average delay per delayed flight in the European air traffic system.

The main cause of delays at analyzed European airports is reactionary delay, which accounts between $20 \%$ and $60 \%$ of total delay, while at the Croatian regional costal airports this share is $75 \%$.

If the delay data between Split Airport and the European air traffic system is compared on the annual level, a significant deviation in the average delay times can be noticed. However, if the delay data at the monthly level (July) is compared, it can be observed that the average delays at Croatian regional coastal airports deviate minimally from the delays recorded in the European air traffic system. The reason for this is high level of traffic, limited infrastructural capacities, and high share of reactionary delays.

The largest share in the number of delays belongs to the national airline Croatia Airlines, which at the same time performed the highest number of aircraft operations. 
Aircraft delays result from a lack of capacities in certain segments of the air traffic system and inadequate communication and coordination between individual subjects (from pre-operation to operation phases). Furthermore, aircraft delays are also affected by numerous variable elements, such as meteorological conditions, that have a stochastic character and in most cases are impossible to predict.

The comparative delay analysis of the Croatian regional coastal airports and the European air traffic system indicates that there is a correlation between them.

Croatian regional coastal airports, even with their low share in European air traffic, still contribute significantly to delay occurrence in the European air traffic network, especially during the peak summer months.

\author{
Dr. sc. MATIJA BRAČIĆ, \\ E-mail: mbracic@fpz.hr \\ Dr. sc. STANISLAV PAVLIN ${ }^{1}$ \\ E-mail: spavlin@fpz.hr \\ Dr. sc. RUŽICA ŠKURLA BABIĆ ${ }^{1}$ \\ E-mail: rskurla@fpz.hr \\ ${ }^{1}$ Sveučilište u Zagrebu, Fakultet prometnih znanosti \\ Vukelićeva 4, 10000 Zagreb, Hrvatska
}

\section{DISTRIBUCIJA UZROKA KAŠNJENJA: EU VS HRVATSKE OBALNE ZRAČNE LUKE}

\section{SAŽETAK}

Porast zračnog prometa u Europi posljednjih je desetljeća prouzročio kašnjenja zrakoplova zbog nedostatnih kapaciteta zračnog prostora i zračnih luka. U radu su, u skladu sa CODA metodologijom, analizirana primarna i reaktivna kašnjenja na određenim europskim zračnim lukama te na obalnim zračnim lukama Republike Hrvatske u 2014. te su klasificirana prema glavnim uzročnicima kašnjenja na letu. Najveći udio u ukupnim minutama kašnjenja na hrvatskim obalnim zračnim lukama je povezan s reaktivnim kašnjenjima (75\%) dok udio tih kašnjenja u ukupnim minutama kašnjenja na većini najzagušenijih europskih zračnih luka iznosi od oko $20 \%$ do oko $60 \%$. Poseban naglasak dan je na analizu rotacijskog reaktivnog kašnjenja te rezultati ukazuju da je udio rotacijskog reaktivnog kašnjenja na Zračnoj luci Split veći nego na odabranim europskim zračnim lukama, što se može objasniti kašnjenjima koja se propagiraju kroz mrežu zračnog prometa i ograničenim kapacitetom zračne luke. Uk upno zabilježeno kašnjenja na hrvatskim obalnim zračnim lukama je manje od ukupno zabilježenih kašnjenja u europskom sustavu zračnog prometa, ali obrasci kašnjenja su vrlo slični, osobito tijekom ljetnih vršnih mjeseci.

\section{KLUČNE RIJEČI}

propagirana kašnjenja zrakoplova; primarna i reaktivna kašnjenja; europske zračne luke;

\section{REFERENCES}

[1] Marsh D, Guest T. A matter of time: air traffic delay in Europe. European Organisation for the Safety of Air
Navigation (EUROCONTROL). Report number: Trends in Air Traffic I Volume 2, 2007.

[2] International Air Transport Association. Airport handling manual. $38^{\text {th }}$ edition. Montreal: International Air Transport Association; 2018.

[3] Marsh D, Wandeler YD. Planning for delay: influence of flight scheduling on airline punctuality. European Organisation for the Safety of Air Navigation (EUROCONTROL). Report number: EUROCONTROL Trends in Air Traffic Volume 7, 2007.

[4] Pearce B. Economic performance of the airline industry. Montreal: International Air Transport Association; 2016.

[5] Van de Vijver E, Derudder B, Witlox F. Air Passenger Transport and Regional Development: Cause and Effect in Europe. Promet - Traffic \& Transportation. 2016;28(2): 143-154.

[6] Jetzki M. The propagation of air transport delays in Europe. PhD thesis. Aachen: RWTH Aachen University; 2009.

[7] Reynolds-Feighan AJ, Button KJ. An assessment of the capacity and congestion levels at European airports. Journal of Air Transport Management. 1999;5(3): 113-134. Available from: https://www.sciencedirect. com/science/article/pii/S096969979900006X [Accessed $19^{\text {th }}$ July 2018].

[8] Campanelli B, Fleurquin P, Eguiluz VM, Ramasco JJ, Arranz A. Extebarria I, Ciruelos C. Modelling reactionary delays in the European air transport network. In: Schaefer D. (ed.) Proceedings of the Fourth SESAR Innovation Days, 25 -27 November 2014, Madrid, Spain. Available from: https://www.sesarju.eu/sites/default/ files/documents/sid/2014/SID\%202014-44.pdf [Accessed 19 July 2018].

[9] Liu J, Li K, Yin M, Zhu X, Han K. Optimizing key parameters of ground delay program with uncertain airport capacity. Journal of Advanced Transportation. 2017; Article ID 7494213: 9 pages. Available from: https:// www.hindawi.com/journals/jat/2017/7494213/ [Accessed 22 July 2018].

[10] Baspinar B, Ure NK, Koyuncu E, Inalhan G. Analysis of delay characteristics of European air traffic through a data-driven airport-centric queuing network model. IFAC-PapersOnLine 2016;49(3): 359-364.

[11] Bai Y. Analysis of aircraft arrival delay and airport ontime performance. PhD thesis. Orlando, FL: University of Central Florida Orlando; 2006.

[12] Xu N, Donohue G, Laskey KB, Chen C-H. Estimation of delay propagation in the national aviation system using Bayesian networks. In: Saunders-Hodge S, Pusch C. (eds.) Proceedings of the $6^{\text {th }}$ USA/Europe Air Traffic Management Research and Development Seminar, 27 - 30 June 2005, Baltimore, USA. Available from: http://icrat.org/seminarContent/seminar6/papers/p_073_IAC.pdf [Accessed 19 July 2018]

[13] Xu N, Laskey KB, Chen C-H, Williams, SC, Sherry, L. Bayesian network analysis of flight delays. In: Watson LS (ed.) Proceedings of the Transportation Research Board 86 ${ }^{\text {th }}$ Annual Meeting, 21 - 25 January 2007, Washington DC, USA. Available from: https:// pdfs.semanticscholar.org/5f66/329de93f1918794b93238d869738706c1910.pdf [Accessed 21 July 2018].

[14] Xu N, Sherry L, Laskey K. Multifactor Model for Predict- 
ing Delays at Us Airports. Transportation Research Record: Journal of the Transportation Research Board. 2008;2052(1): 62-71.

[15] Campanelli B, Fleurquin P, Arranz A, Etxebarria I, Ciruelos C, Eguíluz VM, Ramasco JJ. Comparing the modelling of delay propagation in the US and European air traffic networks. Journal of Air Transport Management. 2016;56(A): 12-18. Available from: http://www.sciencedirect.com/science/article/pii/ S0969699716301016 [Accessed 21 December 2017]

[16] Belkoura S, Maria Peña J, Zanin M. Generation and recovery of airborne delays in air transport. Transportation Research Part C: Emerging Technologies. 2016;69: 436-450. Available from: http://www.sciencedirect. com/science/article/pii/S0968090X16300912 [Accessed 21 December 2017]

[17] Silva HE, Verhoef E, van den Berg V. Airline route structure competition and network policy. Tinbergen Institute. Report number: TI 2013-189/VIII, 2013.

[18] Rosen A. Flight delays on US airlines: The Impact of Congestion Externalities in Hub and Spoke Networks. MSc thesis. Stanford, CA: Stanford University; 2002.

[19] Ater I. Internalization of congestion at US hub airports. Journal of Urban Economics. 2012;72: 196209. Available from: http://www.sciencedirect.com/ science/article/pii/S0094119012000368 [Accessed 21 December 2017]

[20] Wang PTR, Schaefer LA, Wojcik LA. Flight connections and their impacts on delay propagation. The MITRE Corporation. Report number: DTFA01-01-C-00001, 2003.

[21] Cook A, Tanner G, Williams V, Meise G. Dynamic cost indexing - Managing airline delay costs. Journal of Air Transport Management. 2009;15(1): 26-35.

[22] Forbes SJ. The effect of air traffic delays on airline prices. International Journal of Industrial Organization. 2008;26(5): 1218-1232. Available from: https://www.sciencedirect.com/science/article/pii/ S0167718707001555 [Accessed 21 December 2017]

[23] University of Westminster. European airline delay cost reference values. Final report (Version 3.2). Performance Review Unit, European Organisation for the Safety of Air Navigation (EUROCONTROL). Report number: 09-112277-C, 2011.

[24] Stone MJ. Impact of delays and cancellations on travel from small community airports. Tourism and Hospitality Research. 2016.18(2):214-228 Available from: https://doi.org/10.1177/1467358416637252 [ACcessed 21 December 2017]

[25] Federal Aviation Administration. National plan of integrated airport system 2009-2013. US Department of Transport, Federal Aviation Administration. Report number: Section 47103 of Title 49, 2008.

[26] Horonjeff R, McKelvey FX, Sproule WJ, Young S. Planning and Design of Airports. $5^{\text {th }}$ ed. New York, NY: McGraw-Hill Inc.; 2010.
[27] European Union. Communication from the Commission. Community guidelines on financing of airports and start-up aid to airlines departing from regional airports. European Union. Report number: 2005/C 312/01, 2005.

[28] Airport Operations Team. Methodology for Airports being Important to the Network. European Organisation for the Safety of Air Navigation. Action Paper, Report number: AOT/03/AP06, 2013.

[29] International Civil Aviation Organization. Manual on air traffic management system requirements. International Civil Aviation Organization. Report number: 9882, 2008.

[30] International Civil Aviation Organization. EUR region performance framework document. International Civil Aviation Organization. Report number: 030, 2013.

[31] Airport Council International. Guide to airport performance measures. Montreal: Airport Council International; 2012.

[32] Central Office for Delay Analysis. CODA Digest, All-causes delay and cancellations to air transport in Europe - 2014. European Organisation for the Safety of Air Navigation (EUROCONTROL). Report number: CDA_2014_005, 2015.

[33] Performance Review Body (PRB) of the Single European Sky. SES II Performance scheme assessment of national / FAB performance plans with performance targets for the period 2012-2014. European Organisation for the Safety of Air Navigation (EUROCONTROL); 2011.

[34] The European Commission. Commission implementing regulation (EU) No 390/2013 laying down a performance scheme for air navigation services and network functions. European Union. Report number: L 128/1, 2013.

[35] Network Manager nominated by the European Commission. Network operations report 2017. Annex I users view. European Organisation for the Safety of Air Navigation (EUROCONTROL); 2018.

[36] Central Office for Delay Analysis. CODA Digest, All-causes delay and cancellations to air transport in Europe - annual 2015. European Organisation for the Safety of Air Navigation (EUROCONTROL). Report number: CDA_2015_005, 2016.

[37] Central Office for Delay Analysis. CODA Digest, All-causes delay and cancellations to air transport in Europe - 2016. European Organisation for the Safety of Air Navigation (EUROCONTROL). Report number: CDA_2017_005, 2017.

[38] Croatian Bureau of Statistics. Traffic in Airports. Croatian Bureau of Statistics. Report number: 5.1.5/12., 2015.

[39] Split Airport. Split Airport Statistics Analysis. Split: Split Airport; 2015.

[40] Dubrovnik Airport. Dubrovnik Airport Statistics Analysis. Dubrovnik: Dubrovnik Airport; 2015. 